\title{
Biotechnology industry in India: Opportunities or challenges
}

\author{
Abhishek Kumar ${ }^{1 *}$ and Lav Srivastava ${ }^{2}$ \\ ${ }^{1}$ Amity Institute of Biotechnology, Amity University Uttar Pradesh, Lucknow, India. \\ ${ }^{2}$ SDSN Degree College, University of Lucknow, Uttar Pradesh, India.
}

Accepted 27 January, 2011

\begin{abstract}
Biotechnology have touched every corner of the world laying major stress on applications to the environment, drugs, vaccines including a range of biopharmaceuticals, diagnostics, transgenic crops, improved tools for upgrading animal reproduction and quality, useful microbes and food ingredients. The term 'Biotechnology' is coined as amalgamation of biology with technology that includes disciplines like molecular modeling, genomic, bio - informatics, bio - simulation, clinical information and many more. Biotechnology (BT) - derived products worldwide include a range of pharmaceuticals and diagnostics, transgenic food and field crops with desired field and quality characteristics, improved tools for upgrading animal reproduction and quality, useful microbes and food ingredients. Contributing $2 \%$ of global biotech industry, Indian BT employs 20,000 resource persons. Though India has improved its potential to contribute more to this industry, but in spite of infrastructure, funds, manpower, it need to put more efforts on up-grading system by building funding options, venture capitalists, bio-networking, IP development. Government initiatives are harnessing its valuable potential to derive values from technology - led exports and export of technologies. This has enhanced intensively the networking of capabilities and facilities within the country. Biotechnology is in hands of developed countries with superior technology, intellectual scientists and good financials, etc that support the industry but in the current scenario India is becoming an attraction for foreign players ranking 3rd after Japan and Korea in the Asia, considering foreign direct investments (FDls) for biotechnology. Significant opportunities exist for the growth of biotechnology in the region, particularly in the agriculture and healthcare sectors due to the large existing and growing markets for food products and pharmaceuticals for the growing population.
\end{abstract}

Key words: Biotechnology, industry, opportunities, challenges, India.

\section{INTRODUCTION}

"Biotech stocks have outperformed virtually every other index in the first quarter of 2010 and the NASDAQ Biotech Index has climbed back to a point even higher than it was when the market peaked in 2007. The markets are coming back and biotech has come back faster and stronger", said BIO President and CEO Mr.

${ }^{*}$ Corresponding author. E-mail: kumarabhishek1302@gmail. com. Tel: +91 - 9452853335 .
James Greenwood at BIO 2010 in Chicago. Biotechnology, a technology driven science with small product life cycle is moving with a good pace and is expected to replace the position of Information Technology in the upcoming decades Alok (2011).

India, the largest democracy and also known as an emerging economy in the world, has now shifted its focus to this promising industry of future, which is seen as a potential industry. It is one of the 12 - hotspot containing diverse species of flora and fauna and this bio-diversity offers an added advantage for the biotech 


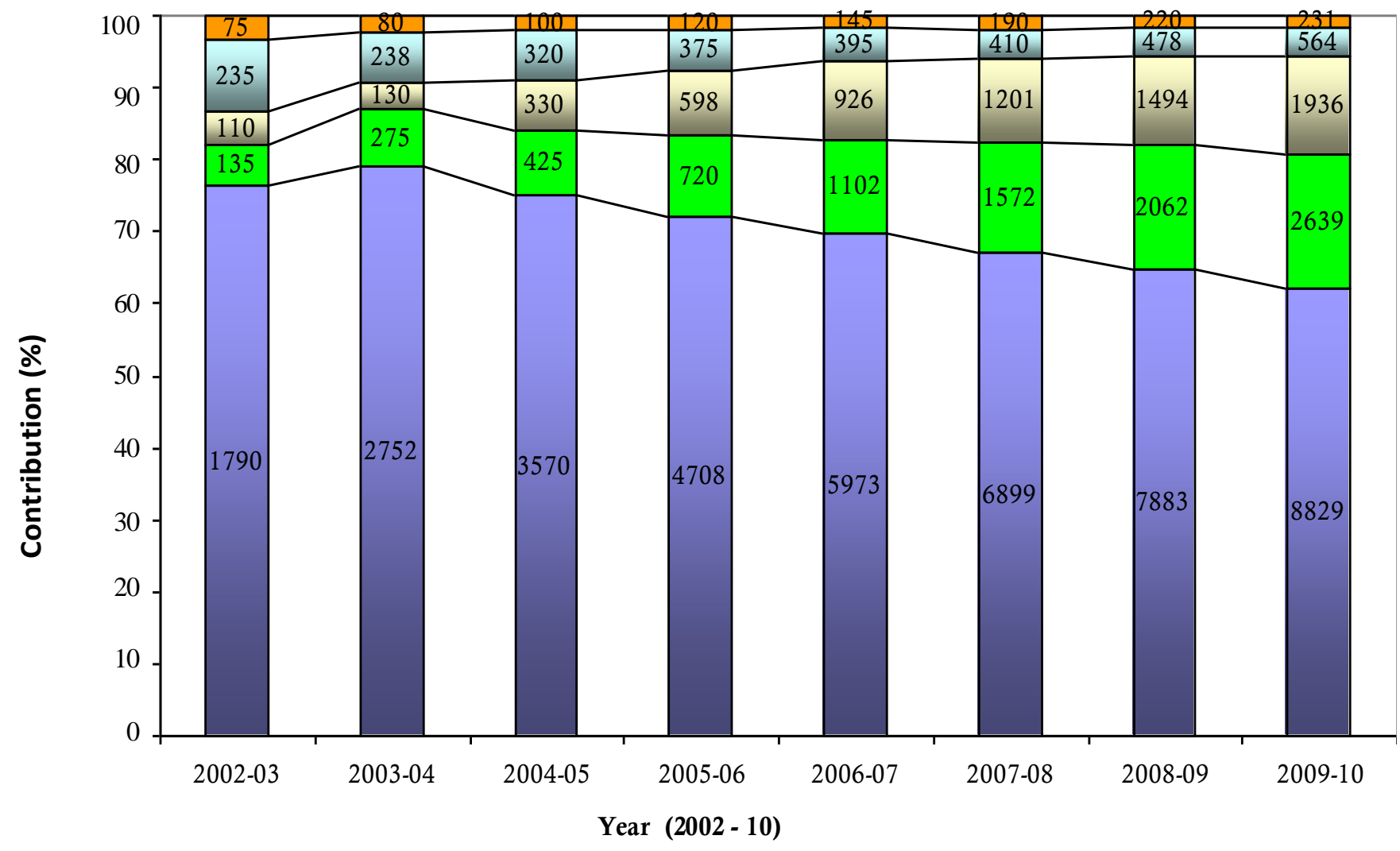

$\square$ Biopharma $\square$ Bioservices $\square$ BioAgri $\square$ BioIndustrial $\square$ Bio Informatics

Figure 1. Indian Biotechnology Industry (2002 to 2010). Source: Biospectrum, June 2010, Vol8, Issue 6, 20.

companies in finding samples, conducting field research much more efficiently. India has one of the largest agriculture sectors in the world with varied climatic zones that also helps in R\&D of different agri-biotech products available world-wide.

Biotechnology market of Asia-Pacific is estimated worth US\$ 41 billion growing at a CAGR of $15 \%$ - Countries like Japan, China, Australia, South Korea, India, Taiwan, New Zealand and Singapore have scaled up to great extent. Japan, China, and Taiwan are the largest Biotechnology markets in the Asia-Pacific region that had a combined market share of nearly $76 \%$ This region has great potential for stem cell research and biogeneric manufacturing. Considering India around 900 industries and institutes in key areas of therapeutics, diagnostics, food processing, tissue culture, plant development, are asset of Indian biotech industry.

The country has a competitive advantage over other countries with large scientific pool with reasonable costs, wealthy $R \& D$ institutions, biological centers of academic excellence, etc.

\section{Core competencies of India}

1. Bioprocess Technology

2. Gene Manipulation of microorganism/animal cells

3. Extraction and isolation of plant/animal products

4. Recombinant DNA Technology

5. Traditional and Molecular Marker assisted breeding

6. Infrastructure in fabricating bio-reactors and processing equipments

Besides above Indian human capital is believed to be the strongest asset for this knowledge-based industry having a large english speaking skill base with 3 million graduates, 700,000 postgraduates and 1,500 $\mathrm{PhDs}$ qualified in biosciences and engineering. It is estimated that $10 \%$ of researchers and $15 \%$ of scientists in Pharma/ Biotech R\&D in USA are of Indian origin.

According to the latest data collected (Figure 1) under given is the scene of Indian biotech industry:

1. The top 20 companies of India contributed almost 
Table 1. Biotech industry (Exports vs. Domestic) 2011 - 12.

\begin{tabular}{|c|c|c|c|c|c|}
\hline \multirow{2}{*}{ Sector } & \multicolumn{3}{|c|}{ Biotech related revenues (Rs. in Crores) } & \multicolumn{2}{|c|}{ \% Share in (2011- 12) } \\
\hline & Exports & Domestic & Total & Exports (\%) & Domestic \%) \\
\hline BioPharma & & & 12679 & & \\
\hline BioServices & & & 3749 & & \\
\hline BioAgri & 9841.7 & 10598.94 & 3050 & 48.14 & 51.85 \\
\hline Biolndustrial & 9841.7 & 10598.94 & 696 & 48.14 & 51.80 \\
\hline Biolnformatics & & & 266 & & \\
\hline TOTAL & & & 20440 & & \\
\hline
\end{tabular}

Table 2. Biotech industry (Exports vs. Domestic) $2010-11$.

\begin{tabular}{llllll}
\hline \multirow{2}{*}{ Sector } & \multicolumn{2}{l}{ Biotech related revenues (Rs. in Crores) } & \multicolumn{2}{c}{ \% Share in (2010 - 11) } \\
\cline { 2 - 6 } & Exports & Domestic & Total & Exports & Domestic \\
\hline BioPharma & $5,535.40$ & $5,109.6$ & 10,645 & 52 & 48 \\
BioServices & $2,986.29$ & 259.68 & $3,345.97$ & 92 & 8 \\
BioAgri & 74.40 & $2,405.60$ & 2,480 & 3 & 97 \\
Biolndustrial & 150.23 & 475.71 & 625.94 & 24 & 76 \\
Biolnformatics & 106.2 & 146.41 & 252.43 & 42 & 58 \\
TOTAL & 8852.34 & 8397.0 & 17249.34 & 51.32 & 48.68 \\
\hline
\end{tabular}

Source: Revenues of Indian biotech sector surge to \$4 bn in FY11, Business Standard, June 17, 2011.

Table 3. Biotech industry (Exports vs. Domestic) 2009 to 2010.

\begin{tabular}{|c|c|c|c|c|c|}
\hline \multirow{2}{*}{ Sector } & \multicolumn{3}{|c|}{ Biotech related revenues (Rs. In Crores) } & \multicolumn{2}{|c|}{$\%$ Share in $(2009-10)$} \\
\hline & Exports & Domestic & Total & Exports & Domestic \\
\hline BioPharma & $4,767.66$ & $4,061.34$ & 8,829 & 54 & 46 \\
\hline BioServices & $2,507.05$ & 131.95 & 2,639 & 95 & 5 \\
\hline BioAgri & 58.08 & $1,877.92$ & 1,936 & 3 & 97 \\
\hline Biolndustrial & 124.08 & 439.92 & 564 & 22 & 78 \\
\hline Biolnformatics & 73.92 & 157.08 & 231 & 32 & 68 \\
\hline TOTAL & $7,530.79$ & $6,668.21$ & 14,199 & 53.04 & 46.96 \\
\hline
\end{tabular}

Source: Biospectrum, June 2010, Vol8, Issue 6, 20.

$20 \%$ towards the total biotech earned revenue.

2. The bio- pharma sector accounted for around $62 \%$ of the market share, with revenues touching US\$ Rs. 8,829 crores growing $12 \%$ over $2008-2010$.

3. The bio-industrial sector achieved revenues worth Rs. 564 crores growing $16 \%$ in $2009-2010$ (Table 1).

4. The bio-services, comprising of clinical research, contract research and contract manufacturing accounted for $31 \%$ with Rs. 2,639 crores.

5. The agriculture biotech sector climbed $37 \%$ thus accounting for 1,936 crores. The number of companies involved in selling Bt cotton seeds have increased to 30 in which Nuziveedu Seeds has highest contribution followed by Rasi Seeds, Mahyco and Monsanto. However, it is a matter of pride that despite of tremensdous challenges in developing novel products from indigenous research and technology, the Indian biotechnology industry has reached US\$ 3bn in 2010 .
Activities of more than 500 firms is contributing towards nurturing this nascent Indian biotechnology industry, moving ahead in a fast pace to achieve its goal of US\$ 10 billion by 2010. (Report - India Brand Equity Foundation, September 2009, www.ibef.org), Table 2 - 5.

Activities of biotech research and business activities are mainly concentrated around large domestic or multinational pharmaceuticals or agricultural companies. Handful of entrepreneurial biotech - firms have spun off from universities, established by academic researchers or funded by venture capitalists.

Many Indian firms are moving towards collaborations with overseas firms to carryout research and product development, contract services, product testing, manufacturing and co marketing. Plant genetic engineering and agricultural biotechnology, with special reference to food, nutritional supplements and nutraceuticals had played significant role in the Indian agriculture scenario 
Table 4. Biotech industry (Exports versus Domestic) 2008 to 2009

\begin{tabular}{lccccc}
\hline \multirow{2}{*}{ Sector } & \multicolumn{2}{c}{ Biotech related revenues (Rs. in Crores) } & \multicolumn{2}{c}{ \% Share in (2008-2009) } \\
\cline { 2 - 6 } & Exports & Domestic & Total & Exports & Domestic \\
\hline BioPharma & $4,868.00$ & $3,015.00$ & $7,883.00$ & 62.00 & 38.00 \\
BioServices & $1,964.00$ & 98.00 & $2,062.00$ & 95.00 & 5.00 \\
BioAgri & 61.00 & $1,433.00$ & $1,494.00$ & 4.00 & 96.00 \\
Biolndustrial & 89.00 & 389.00 & 478.00 & 10.00 & 81.00 \\
Biolnformatics & 170.00 & 50.00 & 220.00 & 77.00 & 23.00 \\
Total & $7,152.00$ & $4,985.00$ & $12,137.00$ & 59.00 & 41.00 \\
\hline
\end{tabular}

Table 5. Biotech industry (Exports versus Domestic) 2007 to 2008.

\begin{tabular}{lccccc}
\hline \multirow{2}{*}{ Sector } & \multicolumn{2}{c}{ Biotech related revenues (Rs. in Crores) } & \multicolumn{2}{c}{ \% Share in (2007-08) } \\
\cline { 2 - 6 } & Exports & Domestic & Total & Exports & Domestic \\
\hline BioPharma & $3,999.90$ & $2,900.00$ & $6,899.90$ & 57.97 & 42.03 \\
BioServices & $1,502.00$ & 70.00 & $1,572.00$ & 95.55 & 4.45 \\
BioAgri & 51.78 & $1,150.00$ & $1,201.78$ & 4.31 & 95.69 \\
Biolndustrial & 30.00 & 380.00 & 410.00 & 7.32 & 92.68 \\
Biolnformatics & 150.00 & 40.00 & 190.00 & 78.95 & 21.05 \\
Total & 5733.68 & 4540.00 & $10,273.68$ & 55.81 & 44.19 \\
\hline
\end{tabular}

Source: BioSpectrum India; Growth slows; June 2009.

despite of initial regulatory obstacles. Indian biotechnology industry is emerging as world Innovator, Collaborator, and Competitor. Many of the Indian biotech firms and institutions have collaborations with western companies and have projects in pipeline. However, still there exist number of issues from $R$ \& $D$ policy to biosafety and bioethical issues of considerations pertaining to the environment and social equity need to be addressed.

\section{New challenges and remedies}

Biotechnology is a horizontal discipline and can be applied to the environment, the design and production of drugs and vaccines. Looking at the industry front it is found that yet there are many challenges.

1. There is a need for development of a strategic roadmap for biotechnology where competitive areas and needs for industry based R\&D should be identified and future plans should be made taking into consideration the competencies and resources of the country. Bt-Industry needs a revolution like green revolution and white revolution which could provide better crops and therapeutics. A strategic map defining major projects such as stem cell research, tissue culture, etc which could provide great tools for the development of mankind. Department also allocated approx. Rs. 902 crores for various projects in 2009 to 2010 , which increased to Rs. 1200 for 2010 to 2011.
2. There is a requirement for Bio-networking which is recognized as an effective tool for interaction, that include formulation of policies and plans to integrate related biotechnology businesses. It would also encompass issues related to intellectual property rights and regulations, biosafety and bioethics. Advice on other concerns as well can be provided by international agencies and more experienced countries. Countries are running in a race of inter competition with small projects in hand and competing for their own product and technologies. However if they combine their synergies towards a big project in hand could lead to bigger success in area of biotechnology.

India's Department of Biotechnology (DBT) has allocated $\$ 72$ million under the Biotechnology Industry Partnership Programme (BIPP). This will now allow the industry to undertake high risk, leading edge research programmes. BIPP is a concept where government partners with Industries for public support on a cost sharing basis for path breaking research creating economically potential IP for the mankind in the area of agriculture, health, bioenergy, green manufacturing, when the scale of the problem has serious consequences for social and economic development Deccan, 2004, (Indian govern-ment allocates \$72 million under Biotechnology Industry Partnership Programme, Export to India, The Trade Council of Denmark, February 3, 2009)

3. Yet there is a need for development of more specialized human resource which could be achieved by 
setting-up of educational programs in biotechnology which should be accessible to the far flung regions too.

Yes, there is a need to develop more specialized manpower which could be placed in areas of superspecialization leading to more skilled human resource for R\&D. Department of Biotechnology has launched several programmes namely, Biotech Industrial Training Programme (BITP) where growing brains could learn during their studies and could develop their skills to generate more intellectual property(s) in Biotechnology. BITP programme especially for North East has ignited the development of more of skilled intellects in biotechnology. BITP programme is run by Biotech Consortium India Limited under the umbrella of Department of Biotechnology, Govt. of India since last 14 years (www.bcil.nic.in/bcil2009/index.asp).

As claimed by Rajan (2010), Executive Vice President and Chief Technology Officer, Paladin Biosciences, Canada - "India has the wealth of scientific expertise and is already emerging as a biotech powerhouse. To realize its full potential, the Indian economy must continue to grow and bring more and more of its people to the global platform, and the government must recognize the importance of innovation - based life science industry." Devendra, 2003. (Biotalk; May 2010; Biospectrum)

4. There is a need of extending the reach biotechnology investigations in the improvement of varieties of plants crops. Introduction of Bt crops is a revolution, but is it helping the people in solving problem of food. There is a problem of availability of food rather than production, food with high nutritional value.

5. The establishment of biotech R\&D laboratories have thrown open new challenges and opportunities for IT applications in India. Harnessing the power of IT, researchers can collect, organize, store, interpret, share, and analyze the biological data such as nucleic acid, protein sequences, structures, functions, pathways and interactions. Large servers are being deployed for solving large genome comparisons, bio-simulations, and molecular modelling problems. Take the case of data mining and visualization software by which, scientists are able to screen data and identify important relationships and drug discovery is made faster leading to lower costs and faster Time to Deliver. IT majors like Sun, HP and IBM are already offering IT hardware and software solutions in the form of blade servers, grid computing solutions, storage solutions, high performance computing solutions, bundled with operating systems like Linux or Unix variants, supported with suitable customized software or user applications. Yet certain problems need addressing.

6. Life sciences researchers face the problem of bringing various data together on a common platform such as gene sequence data, gene expression data, protein structure data and integrating the same data of the same type collected using different technologies and experimental protocols. A researcher cannot effectively mine data until it has been brought together under a common roof. The problem which needs addressing is Data Integration making the process of matching data sources and finding common keys, making judgments of equivalency and semantic relationships, and finally using technology to implement those decisions.

7. There is a need for technical and computational standards (exclusively for biotech) in the case of hardware and software, however, the imperative challenge, faced by modern day researchers is that there is a demand and need for extensive integration of data and applications.

8. Finally, at the end of the day, it is the general public that will use the drugs. It is of paramount importance that the drugs are investigated and, therefore, that those in the biotech industry, ensure that all procedures carried out during the conduct of clinical studies meet the high quality process standards that will be expected.

Clinical trials are one of the major portions in the study of drugs before they are launched into the market. After sales study is also an important task for the industries to check their effect on the consumers. It also provides a scope towards the development of new and combination drugs for the mankind.

\section{Pressures and problems}

Biotechnology is considered a horizontal discipline and includes bioinformatics, molecular modelling, bio-simulation, clinical information and many more. The ultimate goal of this new and emerging field is to enable the discovery of new biological insights, and create a global perspective by unifying principles in biology that can be distinguished.

Extending the reach, biotechnology contributes to the design and production of drugs, vaccines and has greatly led to advancements in agriculture, space technology, industrial, animal health, marine biotechnology, crime detection, anthropology, and bio-warfare. With the fusion of high-powered computing and biology, the field is so much in demand that it has created a huge scope for employment, more with establishment of R\&D labs.

Computer Science, Information Technology (IT) and Biology are merging into a single discipline, the dependency on IT in case of biological research areas like genetics, proteomics and molecular biology is fuelled by the great need for computational analysis.

\section{Conclusion}

After leading the IT bandwagon India has shifted its efforts to biotechnology. The alignment of a vast pool of 
scientific talent, a world class information-technology industry, and a vibrant generic pharmaceutical sector position India to emerge as a significant spot on the global biotech map. Even though in the global biotech market, Indian share is presently just about $2 \%$, the future seems very bright for the country. Biotechnology is a fast emerging sector in India. The consumption of biotech products in India was $\$ 1789 \mathrm{mn}$ during 1999, which is expected to grow up to the tune of $\$ 4270 \mathrm{mn}$ by the end of year 2010.

Biotech industry in India at present is at the threshold of tremendous growth. For example, in the human and animal products segment of the industry alone, the vaccines market alone is valued at US $\$ 230$ million and is growing at $20 \%$. The success of firms like Shanta Biotech and Bharat Biotech emphasized the fact. India's first genetically engineered vaccine, Shanta Biotech's Shanvac against Hepatitis $B$, costs $\$ 4$, less than half the price of similar vaccines marketed by multinational companies.

The investment opportunities in India are very promising. Fresh investments of $145 \mathrm{mn}$ hold the potential of creating a turnover of Rs. $200 \mathrm{mn}$ in the next 5 to 7 years, which could then further be utilized to innovate new products for the global biotech market. India has achieved an amazing lot in a relatively short time.

If India is to become a world-player in biotechnology it should tie up with world-class biotechnological labs. In the US, leading universities are funded by the industry to conduct research for development of biotechnology products. India should also encourage the establishment of private sector and autonomous research institutions. There are some universities in India - The School of Life Science, Jawaharlal Nehru University, Delhi; Madurai Kamraj University, the Tata Institute of Fundamental Research, Bombay; and Indian Institute of Science, Bangalore, along with CSIR Biotech Lab - which do pioneering research in biotechnology. Biotechnology is a vast area having multi-dimensional potential and it is not possible excel in all areas. Therefore, it is imperative to create a niche and develop core competence. Much also depends on political stability and willingness to take risk. Most important is the contribution of the private sector. Some States, particularly Karnataka and Andhra Pradesh, have taken the lead in establishing biotechnology parks.

The desire to create the new market space and product pervades business today. But while innovation is essential, particularly in biotechnology to boost the economy and society, it is truly a commercial necessity for individual companies. In 1966, Harvard Professor Theordore Levitt argued compellingly that the success of most companies/countries hinges more on imitation than innovation. Being a fast follower, he wrote, is a more dependable strategy than being a first mover. In biotechnology it is possible to have a carefully developed method of planning innovative imitation. India has to learn how to make and sell things.

\section{ACKNOWLEDGEMENT}

I would like to acknowledge Prof. P K Seth, CEO, Biotech Park, Prof. Rajesh K Tiwari, Head, AMITY Institute of Biotechnology, AMITY University Uttar Pradesh, Lucknow Campus for providing me immense help and guidance in this research.

\section{REFERENCES}

Alok KS (2011). Biotechnology: The New Horizon for Indian Leadership, VSRD Technical and Non Technical Journal, 2(3):144159.

Biotechs get closer to the tipping point, Biospectrum, Bioevents, June 14, 2010; http://biospectrumindia.ciol.com/cgibin/printer.asp?id=121079.

Deccan Herald (2004). New challenges facing biotechnology, July 08. http://archive.deccanherald.com/deccanherald/july082004/edu9.asp.

Devendra M (2003). Biotechnology in India-Creating a new market space, The Hindu Business Line, Opinion; Bio-tech and Genetics, Jul

30,http://www.thehindubusinessline.in/2003/07/30/stories/200307300 0100900.htm.

Rajan G (2010). "'India has a wealth of scientific expertise", Interview: Paladin Biosciences, Canada, Biospectrum, Biotalk, May 11.

Report- India Brand Equity Foundation, September 2009, www.ibef.org.

The Trade Council of Denmark (2009). Indian government allocates $\$ 72$ million under Biotechnology Industry Partnership Programme, Export to India, February 3. 